\author{
WŁadysŁaW Lasoń, Monika LeŚKiewicz, Magdalena Regulska \\ Zakład Neuroendokrynologii Doświadczalnej, \\ Instytut Farmakologii im. Jerzego Maja PAN \\ Smętna 12, 31-343 Kraków \\ E-mail: lason@if-pan.krakow.pl
}

\title{
ASPEKTY MEDYCZNE I BIOLOGICZNE ZABURZEŃ SNU W PADACZCE
}

\section{WPROWADZENIE}

Od zarania dziejów padaczka (epilepsja) towarzyszyła człowiekowi. Jej spektakularne objawy, takie jak powtarzajace się, nagłe utraty przytomności i silne drgawki, czasami pojawiajacca się piana na ustach i nieartykułowane dźwięki, budziły lęk i podejrzenia o udział sił nieczystych w przyczynach tej choroby (gr. epilamvanein - zawładnięcie, w domyśle przez złego ducha). W starożytnym Egipcie opisywano ja jako święta chorobę, zsyłana na człowieka jako karę przez bogów. Racjonalne stanowisko wobec padaczki reprezentował Hipokrates, który 400 lat p.n.e. opisał ja jako chorobę mózgu, wymagająca leczenia za pomoca leków i diety, a nie czarów. Jego pogląd nie wpłyną jednak w istotnym stopniu na jej postrzeganie i leczenie $\mathrm{w}$ następnych stuleciach. W materiałach Komisji Antropologicznej Akademii Umiejętności w Krakowie z 1826 r. można znaleźć rozdział "Przyczynek do lecznictwa ludowego” dr F. Wereńko, w którym autor pisze: „według ludu zamieszkałego $\mathrm{w}$ guberni mińskiej i witebskiej, ciężka forma padaczki, kadukiem zwana, pochodzi $z$ opętania i leczy się ja nader trudno, wyłącznie tylko egzorcyzmami". Rozwój nauk przyrodniczych i medycznych na przełomie XIX i XX w. pozwolił na wprowadzenie pierwszych skutecznych, choć niedoskonałych leków przeciwpadaczkowych i zapoczatkował nową erę w badaniach nad padaczka. Nie inaczej było ze snem, o którym pisali już najwięksi filozofowie $\mathrm{w}$ starożytnych czasach $\mathrm{w}$ Mezopotamii, Egipcie czy Grecji. Wtedy również zaobserwowano relację pomiędzy odmiennymi sta- nami świadomości, za jakie uważano napady epilepsji i sen, a starożytni wierzyli, że te zjawiska odzwierciedlaja czasowe oddzielenie duszy od ciała. W czasach nowożytnych wzajemne oddziaływanie napadów padaczkowych i snu stało się przedmiotem badań naukowych, kiedy to brytyjski neurolog Sir William Gowers (1845 -1915) zaobserwował, że u niektórych pacjentów $\mathrm{z}$ padaczką, atak drgawek miał miejsce $\mathrm{w}$ czasie snu, a $u$ innych drgawki wysteppowały tylko w ciagu dnia. Wraz $z$ rozwojem techniki EEG (zapis czynności elektrycznej mózgu, ang. electroencephalography) uzyskiwano kolejne dowody na zmiany bioelektrycznej aktywności mózgu w czasie snu i padaczki. Pionierem w tej dziedzinie był amerykański neurolog Frederic Gibbs (1903-1992), który odkrył, że w zapisie EEG pacjentów chorych na padaczkę, w czasie snu pojawiaja się wyładowania drgawkowe. Zwiększona pobudliwość drgawkowa podczas snu rozpoznana dzięki technikom EEG skłoniła badaczy do zaproponowania podziału zespołów padaczkowych ze względu na pojawianie się napadów drgawek w różnych fazach cyklu okołodobowego. Szczególnie zespoły padaczkowe występujace u dzieci wykazują silny zwiazek $z$ fazami snu, również napady drgawek $\mathrm{u}$ dorosłych często maja miejsce w czasie snu albo wywoływane sa jego deprywacją. Wzajemne zależności pomiędzy napadami drgawek, fazami, jakością, zaburzeniami snu oraz lekami przeciwpadaczkowymi stanowia trudny problem i wyzwanie do wypracowania dogodnego modelu terapii dla pacjentów $z$ epilepsja w celu poprawy jakości ich życia. 


\section{PADACZKA - ROZPOWSZECHNIENIE, PRZYCZYNY I PODSTAWOWE MECHANIZMY}

Zgodnie ze współczesna wiedza medyczną padaczka określamy stany chorobowe o różnej etiologii, których wiodacym objawem sa nawracajace i nieprowokowane napady drgawkowe i nie drgawkowe. Padaczka jest częstym schorzeniem neurologicznym; jej rozpowszechnienie wynosi $60 \mathrm{mln}$ chorych na świecie, a w Polsce ok. 400 tys. Ryzyko padaczki u rodzeństwa osoby chorej jest szacowane na poziomie $2,5 \%$, natomiast $u$ potomstwa osoby chorej zwiększa się do 3,4\%. U bliźniąt monozygotycznych ryzyko oceniane jest na poziomie $37 \%$, a u dizygotycznych wynosi $10 \%$. Genetyczna predyspozycja oceniana jest na 40\%. Napad padaczkowy jest definiowany jako kliniczny przejaw nieprawidłowego, nadmiernego i synchronicznego pobudzenia określonej populacji komórek nerwowych. Według nieco innej definicji, napad padaczkowy jest wyrazem nagłej, przejściowej i niekontrolowanej dysfunkcji mózgu, spowodowanej patologiczna aktywnościa komórek nerwowych, której towarzysza zmiany ruchowe, czuciowe i behawioralne. W zależności od regionu mózgu objętego powyższym zaburzeniem, kliniczne objawy napadów padaczkowych przybieraja różnorodne formy, a ich klasyfikacja dzieli je na dwie podstawowe kategorie: napady częściowe (ogniskowe) i napady uogólnione. Najczęstszymi przyczynami napadów padaczkowych sa morfologiczne lub czynnościowe zmiany $\mathrm{w}$ obrębie mózgu oraz wrodzona predyspozycja zwiazana $z$ niskim progiem pobudliwości drgawkowej. Moga to być urazy mechaniczne mózgu, malformacje naczyniowe, stany zapalne mózgu, zatrucia niektórymi substancjami, uszkodzenia okołoporodowe mózgu, odstawienia leków i innych substancji działających na ośrodkowy układ nerwowy (OUN) (alkohol, barbiturany, leki psychotropowe) i guzy mózgu. Ponadto, napady padaczkowe moga być jednym $z$ objawów zaburzeń metabolicznych i elektrolitowych, np. hipoglikemii, skrajnej kwasicy lub zasadowicy, hiponatremii czy hipokalcemii. U około $60 \%$ chorych nie udaje się ustalić żadnego czynnika etiologicznego i wtedy napady padaczkowe klasyfikowane sa jako idiopatyczne. Postępy neurofizjologii i neurochemii umożliwiły w znacznym stopniu wyjaśnienie podstawowych mechanizmów generowania napadów padaczkowych.

\section{NEUROCHEMICZNE PODŁOŻE NAPADÓW PADACZKOWYCH}

Obecnie przeważa pogląd, że podłożem napadów padaczkowych jest zakłócenie rów- nowagi pomiedzy procesami pobudzenia i hamowania w OUN. W mózgu ssaków procesami tymi „zarządzaja” dwa główne neuroprzekaźniki: (i) pobudzający - kwas glutaminowy, który wpływa na aktywność komórek nerwowych działajacc na glutaminianergiczne receptory jonotropowe i metabotropowe oraz (ii) hamujacy - kwas $\gamma$-aminomasłowy (GABA), działajacy poprzez receptory GABA. Jonotropowe receptory glutaminianergiczne, zlokalizowane na kolcach dendrytycznych komórek postsynaptycznych, odpowiadaja za generowanie szybkich potencjałów pobudzajacych (EPSP), natomiast receptory metabotropowe, występujace na presynaptycznych błonach, moduluja sygnały nerwowe generując odpowiedzi wolniejsze i dłuższe. W korze mózgowej ssaków ponad $80 \%$ neuronów to neurony glutaminianergiczne, a $10-20 \%$ to hamujace neurony GABAergiczne. Aktywacja jonotropowych receptorów $\mathrm{GABA}_{\mathrm{A}}$ powoduje hiperpolaryzacje błony komórkowej przez zwiększenie napływu jonów chlorkowych do cytozolu, tym samym obniżając pobudliwość neuronu. Utrzymanie funkcjonalnej równowagi miedzy procesami pobudzenia i hamowania, przy liczebnej przewadze neuronów pobudzajacych, zapewnia dywergencja i konwergencja interneuronów GABA (jeden neuron dzięki rozgałęzieniu aksonu może tworzyć synapsy na tysiącach innych neuronów, a $z$ drugiej strony, każdy neuron glutaminianergiczny może być unerwiany przez wiele neuronów GABAergicznych). Ta efektywna kontrola procesów pobudzajacych może jednak ulec zakłóceniu i wtedy może dochodzić do pojawiania się wyładowań epileptoidalnych, zwiazanych $\mathrm{Z}$ nasileniem dokomórkowych prądów jonowych $\mathrm{Na}^{+}$i $\mathrm{Ca}^{2+}$, hiperaktywnością systemów aminokwasów pobudzajacych, deficytem hamowania spowodowanego zmniejszeniem dokomórkowego prądu chlorkowego i zewnątrzkomórkowych prąów potasowych oraz obniżeniem aktywności układu GABAergicznego. Zatem neurochemicznym podłożem napadów padaczkowych moga być: nieprawidłowa czynność bramkowanych napięciem lub ligandem kanałów sodowych, potasowych, wapniowych i chlorkowych (polimorfizmy, mutacje, deficyt energetyczny) oraz zaburzona funkcjonalna równowaga neuroprzekaźnictwa hamujacego i pobudzajacego. Za hiperaktywnościa układu glutaminianergicznego w padaczce przemawiaja liczne fakty. W hipokampie chorych $z$ padaczka skroniowa stwierdzono zwiększone stężenie kwasu glutaminowego, wzrost glutaminazy aktywowanej fosforanem (ang. phosphate-activated glutaminase, PAG) oraz deficyt syntetazy glutaminianowej w obszarach proliferacji astrogleju (EID i współaut. 2004, 2007; SZELENBERGER i współaut. 
2005). Kluczowe w powstawaniu potencjałów czynnościowych, ale także wyładowań padaczkowych, sa bramkowane napięciem kanały sodowe. Sa one głównym punktem uchwytu wielu leków przeciwpadaczkowych, które obniżaja maksymalna amplitudę prądu sodowego, wydłużaja okres inaktywacji, a więc zmniejszają liczbę dostępnych kanałów sodowych podczas wyładowań o wysokiej częstotliwości (wyładowania napadowe) (RoGAWSKI i LOSCHER 2004). Istotna jest także rola kanałów wapniowych, zwłaszcza w mechanizmach padaczki petit mal, definiowanej jako uogólnione napady nieświadomości. W generowaniu tego typu napadów kluczowa rolę odgrywa niskoprogowy prąd $\mathrm{Ca}^{2+}$, który reguluje aktywność oscylacyjna neuronów wzgórza. W tym typie napadów charakterystyczny jest zapis EEG, w którym obserwuje się obustronnie synchroniczne, wysokonapięciowe wyładowania iglica-fala o częstotliwości $3 \mathrm{~Hz}$. Neurony generuja w tej fazie krótkotrwałe depolaryzacje i salwy potencjałów czynnościowych, ale nie ma w tym przypadku utrzymującej się depolaryzacji lub powtarzalnych potencjałów czynnościowych. Innym ważnym regulatorem pobudliwości błony neuronalnej sa kanały potasowe bramkowane napięciem VGKCs (ang. voltage-gated potassium channels), do których zalicza się kanały Kv7 odpowiadajace za hamowanie depolaryzacji komórek nerwowych (MICELI i współaut. 2012). Modulacja kanałów potasowych $z$ rodziny Kv7 ma znaczacy wpływ na neuronalna pobudliwość, ponieważ kanały te jako jedyne utrzymuja przepływ prądu w czasie inicjacji potencjału czynnościowego i hamuja wyładowania napadowe. W większości przypadków już po kilku minutach napadu padaczkowego następuje samorzutne wygaszanie pobudzenia drgawkowego wskutek aktywacji $\mathrm{Na}^{+} / \mathrm{K}^{+}$ATPazy, wychwytu jonów potasowych i kwasu glutaminowego przez astrocyty oraz wydzielania w trakcie napadu padaczkowego endogennych substancji przeciwdrgawkowych (adenozyna, niektóre neuropeptydy i hamujace aminokwasy). Jeśli czas trwania powtarzalnych napadów przedłuża się powyżej $30 \mathrm{~min}$, to wówczas mamy do czynienia $z$ zagrażajacym życiu chorego stanem padaczkowym (łac. status epilepticus).

Celem leczenia farmakologicznego jest zahamowanie występowania napadów przy zastosowaniu najniższych skutecznych dawek leków, które nie wywołuja działań niepożądanych. Leczenie powinno rozpoczynać się od podawania tylko jednego leku (monoterapia), odpowiedniego dla danej postaci padaczki. Główne punkty uchwytu leków przeciwpadaczkowych obejmuja receptory $\mathrm{GABA}_{\mathrm{A}}$, enzymy $\mathrm{i}$ transportery systemu GABA/glutaminian, zależne od potencjału kanały sodowe, kanały wapniowe $\mathrm{T}$, receptory glutaminianergiczne, enzymy (acetazolamid) i niektóre białka synaptyczne. Nowe molekularne cele dla potencjalnych leków przeciwpadaczkowych obejmuja GABAergiczne $\left(\mathrm{GABA}_{\mathrm{B}}\right)$ i glutaminianergiczne (mGluR) receptory metabotropowe, kanały kationowe $\mathrm{HCN}$ (ang. hyperpolaryzation-activated cyclic nucleotide-gated cation channel), kanały potasowe czy koneksyny (białka międzybłonowe tworzace ścisłe połaczenia, niezbędne do elektrycznej komunikacji międzykomórkowej i przepływu różnych molekuł takich jak jony nieorganiczne, wtórne przekaźników i inne) (MELDRUM i RoGAWSKI 2007, Li i współaut. 2019).

\section{SEN - STAN FIZJOLOGICZNY}

Sen, jak stwierdza uznany ekspert profesor Allan Hobson $z$ Harvard Medical School w Cambridge, wywodzi się $z$ mózgu, jest dla mózgu i pojawia się poprzez mózg (HoBSON 2005). Opisywany jest jako występujący spontanicznie i okresowo stan fizjologiczny, podczas którego ograniczona jest aktywność ruchowa i reaktywność na bodźce. Szybki powrót do czuwania pod wpływem dostatecznie silnych bodźców odróżnia sen od innych stanów, takich jak śpiączka, anestezja czy hibernacja. Sen jest fenomenem i podstawowa biologiczną potrzeba organizmu, bez której nie możne on prawidłowo funkcjonować. Niezakłócony i wystarczająco długi sen (dorosły człowiek najczęściej potrzebuje 7-8 godz. snu na dobę) jest niezbędnym warunkiem dobrego samopoczucia i efektywności w pracy fizycznej i umysłowej, a zwłaszcza dla procesów uczenia się i zapamiętywania. $\mathrm{Na}$ podstawie analizy elektroencefalogramów wyróżniono dwie podstawowe fazy snu: sen bez szybkich ruchów gałek ocznych (ang. non-rapid eye movement, NREM) i sen $z$ szybkimi ruchami gałek ocznych (ang. rapid eye movement, REM). Każdej fazie bioelektrycznej aktywności mózgowej w czasie czuwania i snu przypisane sa określone fale różniące się częstotliwościa, amplituda i stopniem synchronizacji. Pierwsze stadium (N1/S1) fazy NREM, to fale theta o niskiej częstotliwości, w drugim stadium (N2/S2) zaczynaja się pojawiać tzw. wrzeciona snu i K-kompleksy o wysokiej amplitudzie - w tej fazie człowiek traci świadomość. W kolejnych stadiach NREM (N3/S3, S4) pojawiaja się fale delta o wysokiej amplitudzie i niskiej częstotliwości, które charakteryzuja sen głęboki, nazywany też snem wolnofalowym. Cykl snu kończy się faza REM, a więc fazą marzeń sennych, w której zaznacza się aktywność kory mózgowej i hipokampa oraz następuje całkowite rozluźnienie mięśni; czynność EEG w tej fazie to fale o mieszanej 
częstotliwości i niskiej amplitudzie (REDDY i współaut. 2018). Na poziomie molekularnym fazy snu i czuwania regulowane sa nie tylko za pośrednictwem klasycznych neuroprzekaźników, takich jak noradrenalina, serotonina, acetylocholina, histamina, GABA i kwas glutaminowy, ale również wielu innych substancji chemicznych nazywanych czynnikami snu. Do nich zalicza się $\mathrm{m}$. in. adenozynę, hormon wzrostu, prolaktynę, prostaglandynę D2, niektóre cytokiny oraz peptydy $z$ grupy hipokretyn, do których należą oreksyny. Substancje te biora udział w procesie snu w sposób odwracalny, w czasie snu ich stężenie wzrasta, a receptory ulegaja pobudzeniu, natomiast $\mathrm{w}$ czasie czuwania ich aktywność spada. System neuronalny kontrolujacy stany czuwania i snu obejmuje wiele struktur mózgowych, w których poszczególne grupy komórek oddziałujac między soba (pobudzanie i hamowanie docelowych neuronów) generuja reakcje właściwe dla danej fazy (SzELENBERGER 2007). Przy wykorzystaniu technik immunohistochemicznych możliwe było zidentyfikowanie dwóch funkcjonalnie przeciwstawnych systemów neuroanatomicznych regulujacych stan czuwania i snu, obejmujących niektóre jądra podwzgórza i środmózgowia oraz wykorzystujących wymienione powyżej neuroprzekaźniki i regulatory.

\section{WSPÓŁZALEŻNOŚCI POMIĘDZY SNEM A PADACZKA}

Zarówno napady padaczkowe, jak i fazy snu sa przejawem zmian bioelektrycznej aktywności mózgu, a podstawowym narzędziem diagnostycznym w obu zjawiskach jest analiza zapisu elektroencefalograficznego. Zwiazek pomiędzy snem a padaczka jest znany od ponad wieku. Dowiedziono, że zbyt krótki sen może być przyczyna nasilenia napadów padaczkowych, a $z$ drugiej strony, napady drgawkowe i niektóre leki przeciwpadaczkowe moga wpływać negatywnie na ciągłość i jakość snu. Bezsenność jest niezwykle powszechna u osób $z$ padaczka, a jej występowanie szacuje się na $24-55 \%$. U większości pacjentów, zwłaszcza $z$ padaczka płata czołowego i u dzieci z różnymi zespołami padaczkowymi, napady pojawiaja się w nocy, a współwystępowanie zaburzeń snu i napadów padaczkowych obserwuje się u około jednej trzeciej chorych. Zarówno napady padaczkowe przerywajace sen i zaburzenia snu nasilające częstotliwość występowania napadów, pogarszaja ogólny stan zdrowia i jakość życia pacjenta. Objawy zaburzeń snu w padaczce obejmują opóźnienie w zasypianiu, skrócenie czasu snu i zwiększona fragmentację snu. Jakkolwiek napady drgawek w zespołach padaczkowych moga być wyzwalane przez różne czynniki, takie jak stres, odstawienie od alkoholu czy leków przeciwpadaczkowych, wydaje się, że deprywacja snu jest najczęstszym $z$ nich (STANISZEWSKA i współaut. 2017). Zaobserwowano, że w zależności od fazy snu, wyładowania padaczkowe moga być aktywowane lub hamowane. Prawdopodobieństwo wystapienia napadów padaczkowych jest większe zwłaszcza w płytszych stadiach snu NREM, w których obserwuje się wyższy stopień synchronizacji fal niż w czasie fazy REM. Osoby cierpiące na padaczkę narażone sa na większa senność w ciagu dnia, jako następstwo zaburzeń faz snu w czasie nocy oraz w wyniku działania niektórych leków przeciwpadaczkowych, co może również powodować zaburzenia emocjonalne, problemy społeczne i zaburzenia uwagi. Dotyczy to zwłaszcza dzieci, u których występuja zespoły padaczkowe. Badania polisomnograficzne wskazuja, że około $80 \%$ dzieci $z$ epilepsją doświadcza przerywanego snu. Zaburzenia w wystepowaniu faz snu czy bezdech senny to najczęstsze przyczyny tego zjawiska. Często u takich dzieci obserwuje się problemy $z$ zachowaniem w fazie czuwania (NunEs 2010). Obserwacje kliniczne wyraźnie wskazuja na grupę zespołów padaczkowych ściśle zwiazanych $z$ fazami snu, do których zalicza się między innymi encefalopatię padaczkowa wieku dziecięcego, charakteryzująca się napadami w fazie NREM (tzw. elektryczny stan padaczkowy w czasie snu) czy też nocna padaczkę czołowa (ang. autosomal dominant nocturnal frontal lobe epilepsy, ADNFLE), w której występuja wielokrotne epizody drgawkowe w czasie snu, czasem przybierajace postać parasomnii. Dodatkowym czynnikiem obciażającym, współwystępującym $z$ padaczka i snem, jest wcześniej wspomniany bezdech senny, który $z$ jednej strony może nasilać aktywność drgawkowa, a $z$ drugiej, napady drgawek moga przyczyniać się do jego powstawania (GIBBON i współaut. 2019). Zaburzenia snu zwiększaja prawdopodobieństwo wystapienia napadu także u dorosłych pacjentów $z$ idiopatyczna padaczką uogólnioną. Wykazano również, że krótki złożony napad częściowy, występujacy we wczesnych godzinach nocnych, prowadzi do głębokich zaburzeń architektury snu i zmniejsza jego wydajność; wielu pacjentów $z$ napadami nocnymi skarży się na senność w ciagu dnia (MANNI i współaut. 1997, REDDY i współaut. 2018). Warto podkreślić, iż szczególnie u dzieci przesypianie nocy zapewnia im prawidłowy rozwój i przebieg procesów uczenia się i pamięci, a każde przerwanie snu (często w wyniku ataku drgawek) może doprowadzać w przyszłości do zaburzeń procesów poznawczych i problemów psycho-so- 
cjalnych. Uzyskano niezbite dowody, że plastyczność, czyli zdolność mózgu do strukturalnej i funkcjonalnej modyfikacji podczas rozwoju dziecka, jest procesem szczególnie wrażliwym na zaburzenia snu. Badania podstawowe na modelach zwierzęcych jasno wskazuja na nieprawidłowy proces plastyczności komórek mózgu w wyniku deprywacji snu, który doprowadza do niedorozwoju struktur kory mózgowej i pnia mózgu, a na poziomie molekularnym zmienia się ekspresja i funkcja receptorów dla neurotransmiterów (LONGORDO i współaut. 2009). Liczne badania porównawcze wśród dzieci cierpiących na różne przewlekłe schorzenia wskazują, że zwłaszcza mali pacjenci z zespołami padaczkowymi zmagaja się $z$ problemami emocjonalnymi, socjalnymi i poznawczymi. Drgawki, jak również nocne międzynapadowe wyładowania EEG (ang. nocturnal interictal electroencephalograph discharges) zaburzaja ponadto procesy konsolidacji pamięci, w których początkowe nietrwałe ślady pamięciowe zamieniaja się $\mathrm{w}$ formy stabilne i przetrwałe. Według ciekawej hipotezy, podczas snu wolnofalowego, ślady pamięciowe „przechodzą" $z$ tymczasowych magazynów $Z$ hipokampa do kory nowej, a proces ten jest pod kontrola wolnych korowych oscylacji (CHAN i współaut. 2011). Wzajemne zależności łaczace sen $z$ zespołami padaczkowymi to wyzwanie dla terapii, ponieważ leki przeciwpadaczkowe moga przeciwdziałać zaburzeniom snu albo je jeszcze pogarszać. Biorąc pod uwagę wzajemne relacje między snem i padaczka, nie jest zaskakujace, że leki przeciwpadaczkowe maja wpływ na architekturę snu. Efekty te moga być różne w zależności od rodzaju napadów (częściowe lub uogólnione drgawki) i mechanizmów działania leków. Większość leków przeciwdrgawkowych oddziałuje $z$ kanałami jonowymi (sodowymi, wapniowymi, chlorkowymi), receptorami GABA i glutaminianowymi oraz wpływa na procesy uwalniania i wychwytywania pobudzajacych i hamujacych aminokwasów. Generalnie uważa się, że klasyczne leki przeciwdrgawkowe moga zaburzać fazy snu, podczas gdy nowsze leki albo nie wpływaja na sen albo moga pozytywnie wpływać na jego stabilność. Czynnikami niekorzystnie wpływajacymi na sen sa kwas walproinowy i fenytoina, które wydłużaja stadium N1 snu i skracaja sen wolnofalowy. Karbamazepina, antagonista zależnych od potencjału kanałów sodowych, wydłuża fazę snu wolnofalowego, ale dopiero przy dłuższym stosowaniu. Z obserwacji klinicznych wpływu nowszych leków na jakość snu wynika, że lamotrygina poprawia stabilność snu i, co ważne, nie zaburza uwagi ani nie powoduje senności w fazie czuwania, natomiast lewetyracetam za- burza fazy snu wydłużając stadium N2 i może powodować senność w ciagu dnia. Niektóre leki przeciwpadaczkowe, działające poprzez receptor $\mathrm{GABA}_{\mathrm{A}}$ maja właściwości nasenne, a więc korzystnie wpływaja na parametry snu, jednak w fazie czuwania powoduja senność, zaburzają uwage oraz obniżają aktywność psychomotoryczną (WANG i współaut. 2018). Wśród ligandów receptora GABA $_{\mathrm{A}}$ największe zainteresowanie budza te związki, które działaja na receptory umieszczone na zewnatrz szczeliny synaptycznej, nasilajac toniczne hamowanie pobudliwości neuronalnej. W ten sposób działają neurosteroidy (syntetyzowane $w$ neuronach i gleju), silne modulatory receptora GABA $_{A}$ (allopregnanolon), działajace $m$. in. nasennie $i$ przeciwdrgawkowo. W zwierzęcych modelach drgawek wykazano wysoką skuteczność neurosteroidów, a syntetyczny zwiazek ganaksolon jest obecnie w fazie badań klinicznych $\mathrm{w}$ zespołach padaczkowych. Obok leków przeciwpadaczkowych, próbuje się również stosować substancje regulujace cykl czuwania i snu. Jak pokazuja badania, korzystny wpływ na regulację cykli snu i czuwania ma melatonina, a stosowana u osób cierpiących na padaczkę może pomóc poprawić jakość snu bez powodowania znacznych skutków ubocznych (JAIN i współaut. 2015). Istotne znaczenie w regulacji snu ma pobudzajacy neuropeptyd - oreksyna. Wystepuje ona w wysokim stężeniu w podwzgórzu, a zawierajace ja neurony maja projekcję do struktur mózgu zaangażowanych w regulację snu, bezsenności i procesów poznawczych. Dysfunkcję przekaźnictwa oreksynergicznego wykazano w zaburzeniach snu w mysim modelu padaczki płata skroniowego, w którym antagonista receptorów oreksynowych - almoreksant znacznie wydłużał czas trwania snu NREM, a ponadto, zmniejszał częstość występowania ciężkich napadów drgawkowych $\mathrm{u}$ tych zwierzat (RoundTREe i współaut. 2016). Co więcej, oreksyna wydaje się mieć znaczenie w patomechanizmach nagłej, nieoczekiwanej śmierci w padaczce, czyli w tzw. zespole SUDEP (ang. sudden unexpected death in epilepsy). W zwierzęcym modelu SUDEP (myszy $z$ objawami drgawek, bezdechu i bradykardii) zaobserwowano korzystne działanie antagonisty receptorów oreksynowych (IYer i współaut. 2020). Poszukując charakterystycznych markerów, pomocnych w diagnostyce różnicowej parasomnii (zaburzenia w trakcie snu lub przy wybudzaniu - somnambulizm, lęki nocne, koszmary senne) i/lub padaczki wykazano, że stężenie oreksyny A w surowicy krwi pacjentów pediatrycznych wykazuje znamienne różnice w zależności od występowania drgawek w badanych zaburzeniach (KACIŃsKI i współaut. 
2012). Ścisły zwiazek pomiędzy jakościa snu a padaczka skłania do wypracowania jak najlepszego modelu terapii, w której skuteczność leczenia jednego zaburzenia, będzie miało korzystny wpływ na kontrolę drugiego.

\section{PODSUMOWANIE}

W ciagu ostatnich dekad zaznaczył sie znaczny postęp w zrozumieniu klinicznych, neurochemicznych i elektrofizjologicznych aspektów wzajemnej, dwukierunkowej zależności pomiędzy snem a napadami padaczkowymi. Uzyskano dowody, że właściwie dobrane leczenie przeciwpadaczkowe może poprawiać jakość snu. Z kolei, poprawa jakości snu redukuje liczbę i intensywność niektórych rodzajôw napadów padaczkowych. Badania neurofizjologiczne, biochemiczne, immunohistochemiczne i neuroobrazowanie ujawnily niezwykle złożone powiąania neuronalne obszarów mózgowia zaangażowanych $\mathrm{w}$ generowaniu napadów padaczkowych oraz regulacji snu i czuwania. Zarówno w powstawaniu patologicznych napadów padaczkowych, jak i fizjologicznego snu, uczestnicza podobne neuroprzekaźniki i neuromodulatory. Receptory GABA sa nadal głównymi celami w leczeniu zaburzeń zwiazanych ze snem i padaczka. Aktywacja lub nasilenie funkcji tych receptorów poprzez zwiększenie prądów hamujących, zmniejsza pobudliwość neuronów. Oprócz układu GABAergicznego $\mathrm{w}$ kontrolowaniu napadów padaczkowych oraz snu i czuwania, uczestniczą inne, liczne neuroprzekaźniki i neuromodulatory. Szczegółowe poznanie mechanizmów molekularnych i receptorowych tych aktywnych biologicznie substancji powinno umożliwić uzyskanie leków skutecznie zapobiegających napadom padaczkowym, a zarazem normalizujacych fazy snu i czuwania.

\section{Streszczenie}

Padaczka jest przewlekłym schorzeniem neurologicznym, któremu często towarzysza zaburzenia snu. Wzajemne zależności między padaczką a snem sa złożone i tylko częściowo wyjaśnione. Niedobór snu zwiększa podatność organizmu na wystapienie drgawek, a $z$ drugiej strony, drgawki często pojawiające się w nocy, zakłócaja fizjologiczny sen, pogarszając ogólny stan zdrowia i jakość życia chorych. Współwystępowanie padaczki i zaburzeń snu ma szczególnie poważne konsekwencje u dzieci, ponieważ negatywnie wplywa na procesy neurorozwojowe, prowadzac do deficytów behawioralnych, poznawczych i psychosocjalnych. Postępy neurofizjologii i nauk molekularnych ujawnily podstawowe mechanizmy padaczki i snu, akcentujace $\mathrm{w}$ obu zjawiskach role pobudzających i hamujacych neuroprzekaźników, tj. kwasu glutaminowego i kwasu $\gamma$-aminomasłowego (GABA) oraz neuromodulatorów, np. adenozyny, melatoniny i oreksyn. Rezultaty tych badań stwarzają nadzieję na opracowanie nowej strategii farmakoterapii padaczki $z$ korzystnym wpływem na jakość snu.

\section{LITERATURA}

Chan S., Baldeweg T., CRoss J. H., 2011. A role for sleep disruption in cognitive impairment in children with epilepsy. Epilepsy Behav. 20, 435-440.

Eid T., Thomas M. J., Spencer D. D. i współaut., 2004. Loss of glutamine synthetase in the human epileptogenic hippocampus: possible mechanism for raised extracellular glutamate in mesial temporal lobe epilepsy. Lancet 363, 28-37.

EID T., HAMMER J., RUNDÉN-PRAN E. i współaut., 2007. Increased expression of phosphate-activated glutaminase in hippocampal neurons in human mesial temporal lobe epilepsy. Acta Neuropathol. 113, 137-152.

HoBSON J. A., 2005. Sleep is of the brain, by the brain and for the brain. Nature 437,12541256.

IYeR S. H., Aggarwal A., WarRen T. J., Hallgren J., ABel P. W., Simeone T. A., Simeone K. A., 2020. Progressive cardiorespiratory dysfunction in Kv1.1 knockout mice may provide temporal biomarkers of pending sudden unexpected death in epilepsy (SUDEP): The contribution of orexin. Epilepsia 61, 572-588.

Jain S. V., Horn P. S., SimaKaJORnBoon N., BeEBE D. W., Holland K., Byars A. W., GlausER T. A., 2015. Melatonin improves sleep in children with epilepsy: a randomized, double-blind, crossover study. Sleep Med. 16, 637-644.

KACIŃSKI M., BUDZISZEWSKA B., LASOŃ W., ZAJĄC A., SKOWRONEK-BAEA B., LEŚKIEWICZ M., KUBIK A., BASTA-KAIM A., 2012. Level of $S 100 B$ protein, neuron specific enolase, orexin $A$, adiponectin and insulin-like growth factor in serum of pediatric patients suffering from sleep disorders with or without epilepsy. Pharmacol. Rep. 64, 1427-1433.

MANNI R., GALIMBerTi C. A., SARTORI I. i współaut., 1997. Nocturnal partial seizures and arousals/awakenings from sleep: an ambulatory EEG study. Funct. Neurol. 12, 107111.

MeldRum B. S., RogawsKi M. A., 2007. Molecular targets for antiepileptic drug development. Neurotherapeutics 4,18-61.

Miceli F., Vargas E., BeZanilla F., Taglialatela M., 2012. Gating currents from Kv7 channels carrying neuronal hyperexcitability mutations in the voltage-sensing domain. Biophys. J. 102, 1372-1382.

NunES M. L., 2010. Sleep and epilepsy in children: clinical aspects and polysomnography. Epilepsy Res. 89, 121-125.

LI Q., LI Q. Q., JiA J. N., LIU Z. Q., ZHOU H. H., MAO X. Y., 2019. Targeting gap junction in epilepsy: Perspectives and challenges. Biomed. Pharmacother. 109, 57-65.

LONGORDO F., KOPP C., LÜTHI A., 2009. Consequences of sleep deprivation on neurotransmitter receptor expression and function. Eur. J. Neurosci. 29, 1810-1819.

Reddy D. S., Chuang S. H., Hunn D., CRepea A. Z., Magant R., 2018. Neuroendocrine aspects of improving sleep in epilepsy. Epilepsy Res. $147,32-41$.

ROGAWSKI M. A., LÖSCHER W., 2004. The neurobiology of antiepileptic drugs for the treatment of nonepileptic conditions. Nat. Med. 10, 685692.

RoundTREe H. M. , Simeone T. A., Johnson C., MatThews S. A., SAMSON K. K., SimeOne K. A., 2016. Orexin receptor antagonism improves 
sleep and reduces seizures in Kcna1-null mice. Sleep 39, 357-368.

Staniszewska A., MąKA A., Religioni U., OleJNICZAK D., 2017. Sleep disturbances among patients with epilepsy. Neuropsychiatr. Dis. Treat. 13, 1797-1803.

Szelenberger W., 2007. Neurobiologia snu. Pneumonologia i Alergologia Polska 75 (Suppl. 1), 3-8.

Van Der Hel W. S., Notenboom R. G., Bos I. W., Van RiJen P. C., Van Veelen C. W., De GRAAN P. N., 2005. Reduced glutamine syn- thetase in hippocampal areas with neuron loss in temporal lobe epilepsy. Neurology 64, 326333.

WANG Y. Q., ZHANG M. Q., LI R., QU W. M., HuANG Z. L., 2018. The mutual interaction between sleep and epilepsy on the neurobiological basis and therapy. Curr. Neuropharmacol. $16,5-16$.

KOSMOS Vol. 69, 3, 501-507, 2020

WŁadystaw Lasoń, Monika LeśKiewicz, Magdalena Regulska

Department of Experimental Neuroendocrinology, Maj Institute of Pharmacology PAS, 12 Smętna St., 31-343 Krakow, E-mail: lason@if-pan.krakow.pl

MEDICAL AND BIOLOGICAL ASPECTS OF SLEEP DISORDERS IN EPILEPSY

Summary

Epilepsy is a chronic neurological disorder that is often associated with sleep disturbance. The relationship between epilepsy and sleep is complex and only partially explained. Sleep deprivation increases the body's susceptibility to seizures, and on the other hand, seizures that often occur at night disrupt physiological sleep, worsening the overall health and quality of life of patients. The coexistence of epilepsy and sleep disorders has particularly serious consequences in children as it negatively affects neurodevelopmental processes, leading to behavioral, cognitive and psychosocial deficits. Advances in neurophysiology and molecular sciences have revealed the basic mechanisms of epilepsy and sleep, emphasizing the role of excitatory and inhibitory neurotransmitters, i.e. glutamic acid and $\gamma$-aminobutyric acid (GABA), and neuromodulators, e.g. adenosine, melatonin and orexins, in both phenomena. The results of these studies offer hope for the development of a new epilepsy pharmacotherapy strategy with beneficial effects on sleep quality.

Key words: antiepileptics, brain, epilepsy, neuromodulators, neurotransmitters, sleep 